\title{
Carbon and nutrient contents in the miscellaneous fraction of litterfall under different thinning intensities in a semiarid Pinus halepensis afforestation
}

\author{
Carmen Segura ${ }^{(1)}$, \\ Emilia Fernández-Ondoño ${ }^{(1)}$, \\ M Noelia Jiménez ${ }^{(2)}$, \\ Francisco B Navarro ${ }^{(3)}$
}

(1) Department of Soil Science and Agricultural Chemistry, Faculty of Science, University of Granada, C/Severo Ochoa s/n, 18071 Granada (Spain); (2) Department of Botany, Faculty of Pharmacy, University of Granada, Campus de Cartuja, 18071 Granada (Spain); (3) Area of Agriculture and Environment, Institute of Agricultural Research and Training of Andalusia (IFAPA), Government of Andalusia, Camino de Purchil s/n, 18004 Granada (Spain)

@ Carmen Segura (carmensq@correo.ugr.es)

Received: Jun 27, 2018 - Accepted: May 02, 2019

Citation: Segura C, Fernández-Ondoño E, Jiménez MN, Navarro FB (2019). Carbon and nutrient contents in the miscellaneous fraction of litterfall under different thinning intensities in a semiarid Pinus halepensis afforestation. iForest 12: 375-382. - doi: 10.3832/ifor2907-012 [online 2019-07-12]

Communicated by: Giorgio Alberti

Litterfall evaluation and the effects caused by forestry practices provide valuable information on nutrient-cycle dynamics in managed forests. So far, most of the studies have focused on leaf-fall, omitting other litterfall fractions that can be also relevant for forest and soil modelling in a global change context. With this aim the miscellaneous fraction was quantified in a Pinus halepensis afforestation in the semiarid SE of Spain five years after four different thinning regimes were applied (T75: 75\% of mean basal area removed; T60: 60\%; T48: 48\%; and T0: no thinning). Concentrations and pools ( $\left.\mathrm{kg} \mathrm{ha}^{-1}\right)$ of carbon and nutrients in the miscellanea fraction were monthly analysed for $\mathrm{C}$ and $\mathrm{N}$ (June 2010-May 2013), and for P, K, Na, Ca, Mg, Fe, Zn, and Mn (June 2011May 2013). No differences in concentrations of carbon and nutrients were found among treatments with the exception of $\mathrm{N}$, which showed significant differences between T75 and T60 plots. For pools, a high variability was found over time with maximum $\mathrm{C}$ and $\mathrm{N}$ pools found during spring, likely reflecting the influence of Thaumetopoea pityocampa attacks. Thinning affected $\mathrm{C}, \mathrm{N}$, $\mathrm{Mn}$, and $\mathrm{Zn}$ pools in 2011-2012 period, and $\mathrm{P}, \mathrm{K}, \mathrm{Ca}, \mathrm{Mg}, \mathrm{Mn}, \mathrm{Fe}$, and $\mathrm{Zn}$ pools in 2012-2013. Significant differences were mainly found between the most intensive treatment (T75) and unthinned plots (T0). The percentage of annual mean $C$ and nutrient pools in miscellanea showed the importance of its monitoring, with pools that represented from $43.0 \%$ to $57.9 \%$ of the total litterfall for $C\left(278.81-746.01 \mathrm{~kg} \mathrm{ha}^{-1} \mathrm{yr}^{-1}\right), \mathrm{N}\left(4.18-10.44 \mathrm{~kg} \mathrm{ha}^{-1} \mathrm{yr}^{-1}\right)$, and $\mathrm{P}(0.37-1.43$ $\left.\mathrm{kg} \mathrm{ha}^{-1} \mathrm{yr}^{-1}\right)$. Our results stress the high relevance of miscellany monitoring in order to gain a better understanding of nutrient cycles in forest ecosystems.

Keywords: Mediterranean Region, Aleppo Pine, Micro- and Macronutrient Concentrations, Nutrient Dynamics, C Inputs, Pine Processionary

\section{Introduction}

The understanding of litterfall production, controlled mainly by climatic and edaphic factors, and its chemical composition provide useful information about the nutrient cycle and ecosystem productivity as well as data to estimate carbon sequestration in the soil (Berg \& Meentemeyer 2001, Bernier et al. 2008, Andivia et al. 2018). Despite the surge in litterfall studies and data availability in the recent years, few attempts have been made to evaluate the effects of forest management on litterfall dynamics and pools of carbon and nutrients from the different litterfall fractions other than leaves (twigs, bark fragments, seeds, flowers, cones, etc.).

Thinning, which is among the most common forestry practices, has been proposed as an effective and suitable method to reduce stress by competition in Mediterranean high-density pine plantations in semiarid regions (Sánchez-Miranda et al. 2016, Ruiz-Peinado et al. 2017). In this way, thinning may increase resilience to extreme drought events and climate warming (Sohn et al. 2016, Johnson et al. 2017, Jiménez et al. 2019).

Most of the thinning studies on conifer litterfall have focused on needlefall as the main factor affecting the nutrient inputs to the soil. However, there is a lack of knowledge about how other litterfall fractions (twigs, bark, cones, seeds, pollen, insect frass, etc.) could be influenced by thinning and their effects on nutrient cycles. In contrast to needlefall, without difficulties in its classification, the miscellanea fraction encompasses a wide variety of fallen organic elements, depending on the reference consulted (Finér 1996, Blanco et al. 2006, Zhou et al. 2014). For instance, litterfall can be composed of bark, cones, and leaves from other non-pine species, besides pollen or insect frass, while bark and cones are an independent fraction for authors such as Bernier et al. (2008).

All of these components could also be considered as an important source of $\mathrm{C}$ and nutrient returning to the soil in Mediterranean areas (Blanco et al. 2008, Díaz-Pinés et al. 2011, Jiménez \& Navarro 2016). Moreover, miscellanea temporal dynamics in a forest can provide valuable information regarding pest outbreaks or exceptional climatic events, including strong winds and storms (Li et al. 2005, Navarro et al. 2013, Portillo-Estrada et al. 2013). Unfortunately, 
information on how miscellanea respond to forest management is scarce and limited for pine forests in general, and for Pinus halepensis Mill. forests in particular. In this sense, only few authors have reported the effect of thinning on the amount of litterfall and its chemical composition depending on the treatment intensity (Blanco et al. 2008, Lado-Monserrat et al. 2016). These latest authors estimated the thinning effects on miscellaneous fraction in a naturally regenerated $P$. halepensis forest, composed of non-specified material other than P. halepensis, and on C, N, P, K, Ca and $\mathrm{Mg}$ concentrations. Although miscellaneous nutrient concentrations were reported, these authors did not provide information related to nutrient pools ( $\mathrm{kg}$ $h a^{-1}$ ) in each litterfall fraction and did not specify the exact composition of the miscellaneous fraction studied.

In previous research, we investigated the effect of four thinning intensities on $P$. halepensis afforestation in the SE Spain over three years at different levels. Firstly, it was reported the thinning effects on foliar carbon and nutrient concentrations ( $\mathrm{Ji}$ ménez \& Navarro 2015). Secondly, litterfall production and how it was affected by thinning were specified for needles, twigs, woody material, and miscellaneous fractions (Jiménez \& Navarro 2016). In that study, it was demonstrated that thinning did not affect the amount of miscellanea, which constituted around $44.5-48.0 \%$ of the total Aleppo pine litterfall biomass, with annual maximum peaks coinciding with the fall of tent-caterpillar nests and frass. Finally, it was showed that thinning affects both concentrations and pools of carbon and nutrients in the needlefall fraction (Segura et al. 2017), although miscellaneous fraction had not been studied. Therefore, in the present study, our main aims were: (i) to assess the effect of thinning intensities on carbon, macro- ( N, P, K, Ca, Mg, and $\mathrm{Na})$, and micronutrient ( $\mathrm{Mn}, \mathrm{Fe}$, and $\mathrm{Zn}$ )

Tab. 1 - Final tree density (tree ha ${ }^{-1}$ ) after thinning in 2005 and stand characteristics measured just after thinning treatments in 2005, 2010, and 2012 in afforested plots. Thinning treatments: (T75) $75 \%$ of basal area removed; (T60) $60 \%$ of basal area removed; (T48) $48 \%$ of basal area removed; (To) no thinning. Mean \pm standard deviation is shown. (DBH): Diameter at breast height; (BA): basal area.

\begin{tabular}{ccccc}
\hline Treatment & $\begin{array}{c}\text { Density } \\
(\text { tree ha }\end{array}$ & Year & $\begin{array}{c}\text { DBH } \\
(\mathbf{c m})\end{array}$ & $\begin{array}{c}\text { BA } \\
\left(\mathbf{m}^{2} \mathbf{h a}^{-1}\right)\end{array}$ \\
\hline T75 & $325 \pm 68.84$ & 2005 & $5.49 \pm 1.59$ & $0.83 \pm 0.25$ \\
& & 2010 & $10.05 \pm 2.70$ & $2.60 \pm 0.56$ \\
& & 2012 & $12.10 \pm 3.14$ & $4.06 \pm 0.57$ \\
T60 & $513 \pm 77.73$ & 2005 & $5.43 \pm 1.77$ & $1.31 \pm 0.48$ \\
& & 2010 & $10.09 \pm 2.69$ & $4.12 \pm 0.95$ \\
& & 2012 & $11.87 \pm 3.00$ & $5.35 \pm 1.79$ \\
T48 & $681 \pm 68.84$ & 2005 & $5.33 \pm 2.01$ & $1.73 \pm 0.56$ \\
& & 2010 & $9.11 \pm 2.88$ & $4.71 \pm 0.81$ \\
& & 2012 & $10.63 \pm 3.15$ & $6.33 \pm 0.94$ \\
T0 & $1450 \pm 266.93$ & 2005 & $5.09 \pm 1.77$ & $3.30 \pm 0.32$ \\
& & 2010 & $7.87 \pm 2.60$ & $7.79 \pm 1.43$ \\
& & 2012 & $8.90 \pm 2.88$ & $9.93 \pm 1.88$ \\
\hline
\end{tabular}

(FAO/ISRIC 1998) with a considerable surface stoniness. As a result, the soils show an Ap horizon $(0-25 \mathrm{~cm})$ strongly resembling the $\mathrm{Bw}$ one. A petrocalcic horizon $\left(40-60 \% \mathrm{CaCO}_{3}\right)$ is developed at $35-40 \mathrm{~cm}$.

In 1995, part of the property was planted with Pinus halepensis (Aleppo pine) at a density of approximately 1500 trees $\mathrm{ha}^{-1}$.

\section{Field methods and laboratory analyses}

In 2005, ten years after planting, four thinning treatments based on different mean basal area removed were performed on 16 randomly $20 \times 20 \mathrm{~m}$ plots: $\mathrm{T} 75=75 \%$ of basal area removed; T60 $=60 \%$ of basal area removed; $\mathrm{T} 48=48 \%$ of basal area removed; and To = no thinning. The final tree density (tree ha ${ }^{-1}$ ) was measured just after thinning treatments in 2005 whereas the basal area (BA, $\mathrm{m}^{2} \mathrm{ha}^{-1}$ ) and the diameter at breast height $(\mathrm{DBH}, \mathrm{cm})$ were measured in the plots in 2005, 2010 and 2012 (Tab. 1).

For a determination of the litterfall production $\left(\mathrm{kg} \mathrm{ha}^{-1}\right), 96$ circular traps (4 treatments $\times 4$ plots per treatment $\times 2$ randomly assigned trees per plot $\times 3$ circular traps per tree $=96$ ) were distributed and monitored monthly from June 2010 to May 2013 (see Jiménez \& Navarro 2016, for more details). Each month, the litter trapped was collected in plastic bags and taken to the laboratory to separate into four fractions: woody material (bark and cone fragments), twigs/branches (diameter $<1 \mathrm{~cm}$ ), needles, and miscellany (seeds, bracts, pollen, buds, residual matter, and frass from pest), according to Bernier et al. (2008) methodology. The samples sorted into the four fractions were oven dried for 24-48 $\mathrm{h}$ at $70^{\circ} \mathrm{C}$ and weighed.

Jiménez \& Navarro (2016) extrapolated each litterfall fraction ( $\mathrm{kg}$ tree ${ }^{-1}$ ) from traps multiplying the mean fraction values $\left(\mathrm{g} \mathrm{m}^{-2}\right)$ in each stand by each individual tree canopy cover $\left(\mathrm{m}^{2}\right)$. Then, litterfall fractions at the plot level were calculated by adding up the litterfall fractions values from each individual tree in the plot and converting it to $\mathrm{kg} \mathrm{ha}^{-1}$. As a result, Jiménez \& Navarro (2016) reported the monthly production $\left(\mathrm{kg} \mathrm{ha}^{-1}\right)$ of each litterfall fraction for each thinning treatment. They observed that needles and miscellanea represented most of the amount of litterfall recorded from June 2010 to May 2013: between 48.0 to $51.4 \%$ for needlefall and $44.5-48.0 \%$ for miscellany, depending on the thinning treatment. On the contrary, both woody material and twigs/branches were minority fractions (2.8-3.9\% and $0.4-0.9 \%$, respectively) and their nutrient concentrations were not analysed.

Similarly as we proceeded with needlefall (Segura et al. 2017), to analyse carbon and nutrient concentrations in miscellanea fraction, the miscellany samples collected (three samples per pine $x$ two pines in each plot) were lumped together after being weighed, and milled. A total of 16 dried miscellany samples were obtained per month ( 4 treatments $\times 4$ plots $=16$ samples 
per month), although there were some months in which litterfall was absent.

The miscellaneous samples were dried at $60{ }^{\circ} \mathrm{C}$ in an oven to constant weight and pulverized. To determine monthly element concentrations, the samples were digested in a microwave oven and then extracted with $\mathrm{HCl}(2 \%)$. Ca, Mg, K, Na, Mn, Fe, and Zn were determined by atomic-absorption spectrophotometry. $\mathrm{P}$ was analysed by V/UV using the spectrophotometry nitromolybdovanadate method. $\mathrm{C}$ and $\mathrm{N}$ were assayed using an Elemental Analyzer (TruSpec $^{\circledast}$ CN 2.4, LECO, St. Joseph, MI, USA).

$\mathrm{C}$ and $\mathrm{N}$ were analysed for 36 months (June 2010-May 2013), and P, K, Na, Ca, Mg, $\mathrm{Mn}, \mathrm{Fe}$, and $\mathrm{Zn}$ concentration were analysed for 24 months (June 2011-May 2013).

\section{Calculations and statistical analyses}

The C, macro, and micronutrient pools in miscellanea in each plot were calculated by multiplying the monthly miscellanea production $\left(\mathrm{kg} \mathrm{ha}^{-1}\right)$ provided by Jiménez $\& \mathrm{Na}$ varro (2016) by the corresponding monthly element concentration (\% for macronutrients and $C$, and ppm for micronutrients, both transformed to $\mathrm{kg} \mathrm{kg}^{-1}$ ).

The monthly dynamics were studied in miscellanea for $\mathrm{C}$ and $\mathrm{N}$ for both concentrations and pools $(\mathrm{kg}$ ha-1) over 36 months. The effects of the thinning treatments on miscellanea elements (concentrations and total amount in $\mathrm{kg} \mathrm{ha}^{-1}$ ) over time were evaluated using repeated-measures ANOVAs (RM-ANOVAs). At least 3 replicates per treatment were required to include a given month in this statistical analysis.

One-way ANOVA was used to assess the differences among the thinning treatments

Tab. 2 - Mean miscellaneous carbon and nutrient concentrations measured monthly in Pinus halepensis afforestation for each thinning treatment $(\mathrm{N}=4)$. Mean (\% for $\mathrm{C}, \mathrm{N}, \mathrm{P}$, $\mathrm{K}, \mathrm{Ca}, \mathrm{Mg}$, and $\mathrm{Na} ; \mu \mathrm{g} \mathrm{g}^{-1}$ for $\mathrm{Mn}, \mathrm{Fe}$, and $\left.\mathrm{Zn}\right) \pm$ standard deviation are reported. Thin ning treatments: (T75) 75\% of basal area removed; (T60) 60\%; (T48) 48\%; (To) no thinning. Different letters in the same row indicate significant differences $(p<0.05)$ among treatments.

\begin{tabular}{lcrrr}
\hline \multirow{2}{*}{ Nutrient } & \multicolumn{4}{c}{ Thinning treatments } \\
\cline { 2 - 5 } & \multicolumn{1}{c}{ T75 } & \multicolumn{1}{c}{ T60 } & \multicolumn{1}{c}{ T48 } & T0 \\
\hline $\mathrm{C}$ & $46.31 \pm 3.98^{\mathrm{a}}$ & $46.50 \pm 4.26^{\mathrm{a}}$ & $46.32 \pm 5.33^{\mathrm{a}}$ & $46.32 \pm 4.30^{\mathrm{a}}$ \\
$\mathrm{N}$ & $1.15 \pm 0.52^{\mathrm{a}}$ & $1.02 \pm 0.54^{\mathrm{b}}$ & $1.03 \pm 0.48^{\mathrm{ab}}$ & $1.10 \pm 0.41^{\mathrm{ab}}$ \\
$\mathrm{P}$ & $0.08 \pm 0.01^{\mathrm{a}}$ & $0.08 \pm 0.01^{\mathrm{a}}$ & $0.08 \pm 0.01^{\mathrm{a}}$ & $0.08 \pm 0.02^{\mathrm{a}}$ \\
$\mathrm{K}$ & $0.08 \pm 0.04^{\mathrm{a}}$ & $0.07 \pm 0.03^{\mathrm{a}}$ & $0.08 \pm 0.03^{\mathrm{a}}$ & $0.08 \pm 0.03^{\mathrm{a}}$ \\
$\mathrm{Ca}$ & $2.37 \pm 0.99^{\mathrm{a}}$ & $2.15 \pm 0.82^{\mathrm{a}}$ & $1.94 \pm 0.64^{\mathrm{a}}$ & $2.18 \pm 0.76^{\mathrm{a}}$ \\
$\mathrm{Mg}$ & $0.24 \pm 0.05^{\mathrm{a}}$ & $0.22 \pm 0.05^{\mathrm{a}}$ & $0.22 \pm 0.05^{\mathrm{a}}$ & $0.24 \pm 0.05^{\mathrm{a}}$ \\
$\mathrm{Na}$ & $0.07 \pm 0.06^{\mathrm{a}}$ & $0.06 \pm 0.05^{\mathrm{a}}$ & $0.04 \pm 0.04^{\mathrm{a}}$ & $0.05 \pm 0.05^{\mathrm{a}}$ \\
$\mathrm{Mn}$ & $52.46 \pm 22.15^{\mathrm{a}}$ & $48.35 \pm 19.18^{\mathrm{a}}$ & $73.34 \pm 48.44^{\mathrm{a}}$ & $55.22 \pm 17.65^{\mathrm{a}}$ \\
$\mathrm{Fe}$ & $754.48 \pm 469.46^{\mathrm{a}}$ & $751.78 \pm 422.84^{\mathrm{a}}$ & $893.98 \pm 509.04^{\mathrm{a}}$ & $741.02 \pm 479.33^{\mathrm{a}}$ \\
$\mathrm{Zn}$ & $23.73 \pm 7.90^{\mathrm{a}}$ & $17.04 \pm 7.08^{\mathrm{a}}$ & $18.42 \pm 7.50^{\mathrm{a}}$ & $18.23 \pm 8.76^{\mathrm{a}}$ \\
\hline \multicolumn{5}{c}{}
\end{tabular}

for the annual and total amounts of miscellaneous $C$ and nutrients. Non-parametric tests were used in the case of violating homoscedasticity and normality assumptions. A Kruskal-Wallis test was run to evaluate the global differences in miscellanea-elements concentration and pools of $C$ and nutrient in the miscellaneous fraction.

$\mathrm{C}$ and nutrient pools and $\mathrm{C} / \mathrm{N}$ ratio in miscellanea and needlefall, the latter reported previously by Segura et al. (2017), were analysed by a paired $t$-test. Two years of the study period, from June 2011 to May 2013, were used to compare $\mathrm{P}, \mathrm{K}, \mathrm{Na}, \mathrm{Ca}, \mathrm{Mg}$, $\mathrm{Mn}, \mathrm{Fe}$, and $\mathrm{Zn}$ pools $\left(\mathrm{kg} \mathrm{ha}^{-1}\right)$. For $\mathrm{C}, \mathrm{N}$, and $\mathrm{C} / \mathrm{N}$ ratio we used the data corresponding to three years (from June 2010 to May 2013).
Pairwise comparisons tests were applied when significant differences were detected by RM-ANOVA, one-way ANOVA, and Kruskal-Wallis analyses (LSD and Tukey). Significant differences were evaluated at the 0.05 level. All statistical analyses were performed using the software program STATISTIX ver. 9.0 (Analytical Software, Tallahassee, FL, USA).

\section{Results}

\section{Mean $C$ and nutrient concentrations}

After $C$, the most abundant element in miscellaneous fraction in the Aleppo pine afforestation was Ca (Tab. 2). No differences between thinning intensities were found in concentrations for the most of
Fig. 1 - Monthly dynamic concentrations of $\mathrm{C}$ and $\mathrm{N}$ (\%) in the miscellaneous fraction of Pinus halepensis litterfall in each thinning treatment (mean \pm standard deviation). (T75): $75 \%$ of basal area removed; (T60): $60 \%$ of basal area removed; (T48): $48 \%$ of basal area removed; (To): no thinning.

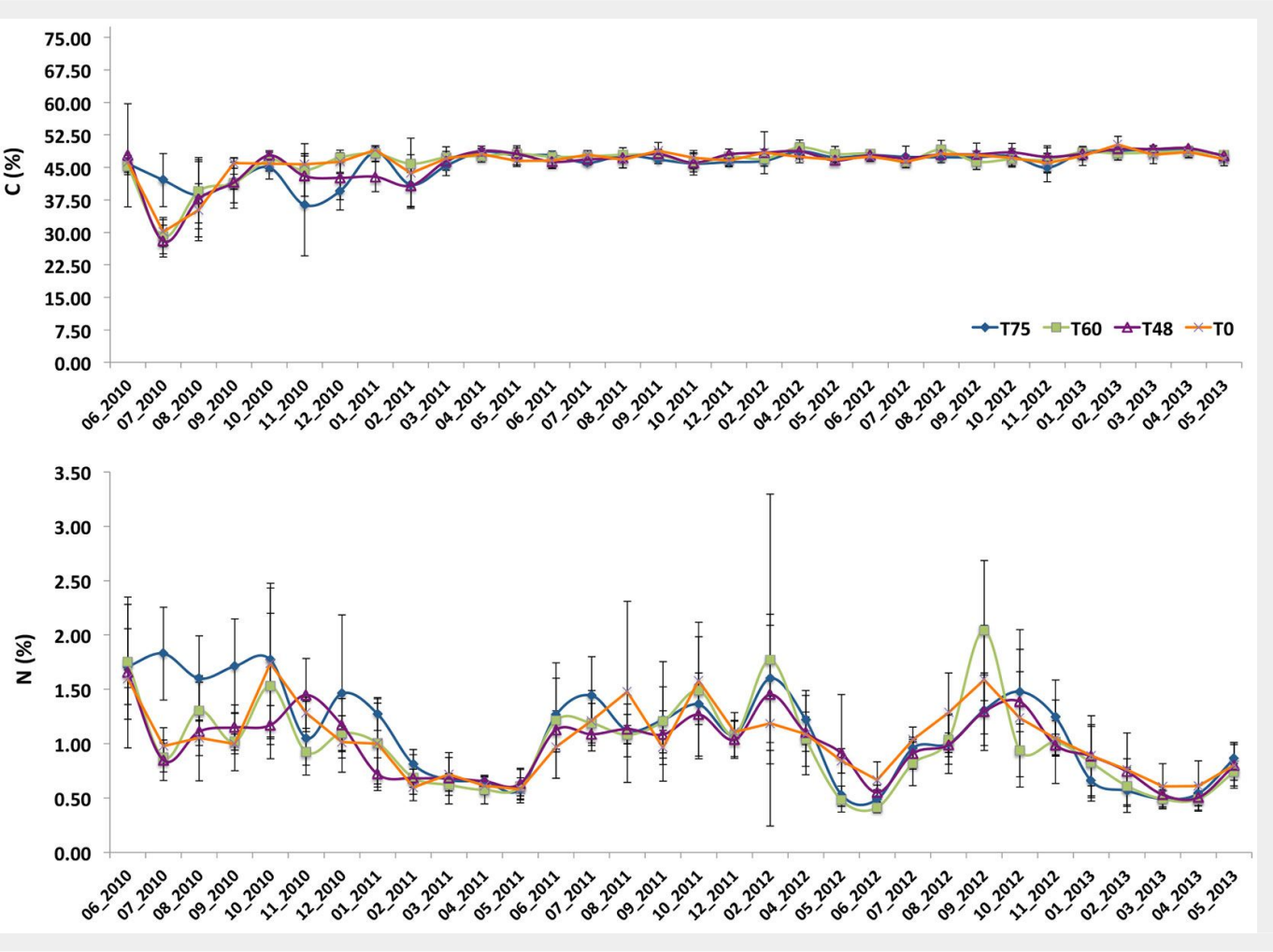




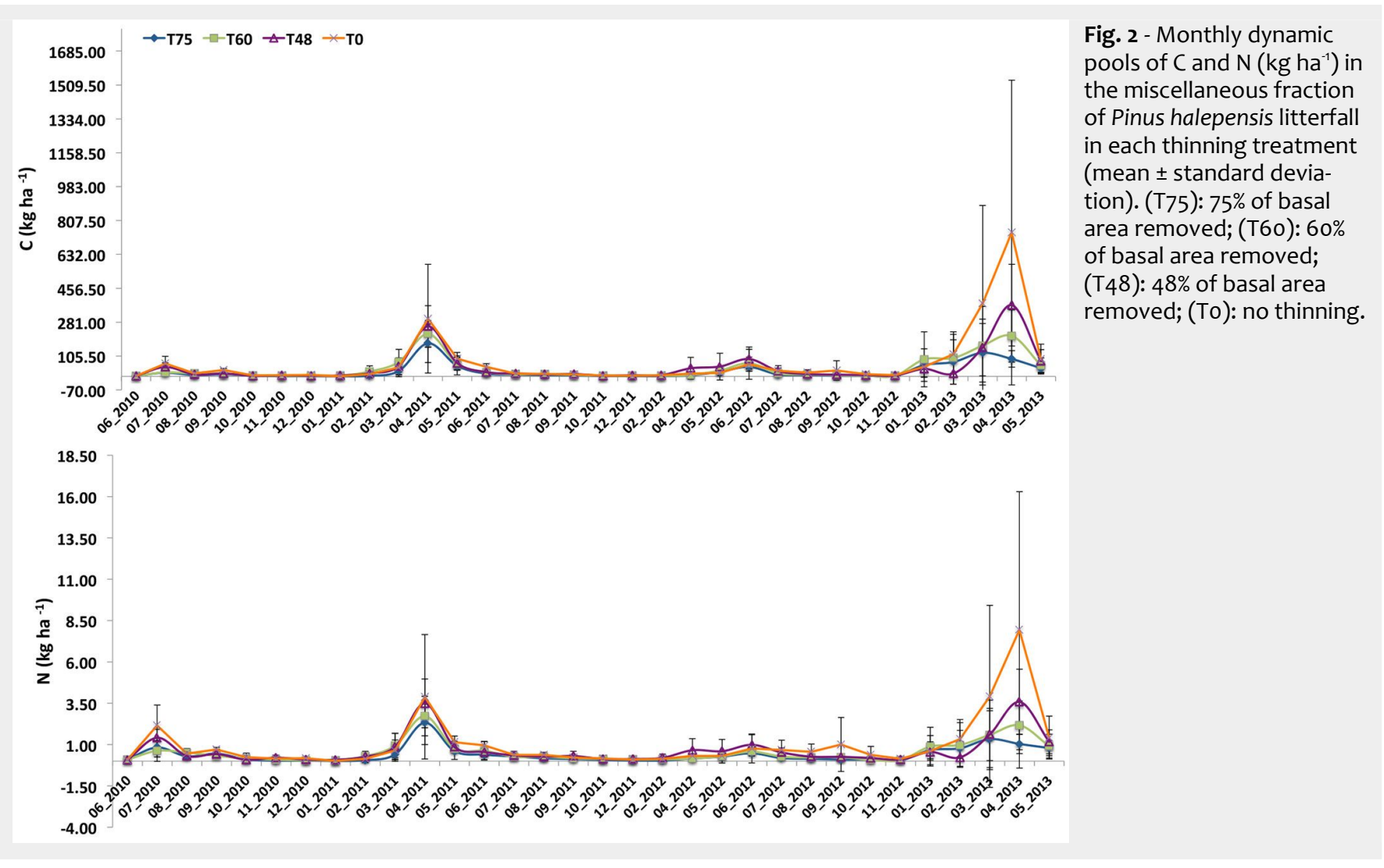

the analysed elements, with the exception of $\mathrm{N}$. The $\mathrm{N}$ concentration was significantly higher in T75 with respect to T60 but no differed from the other treatments $(\mathrm{df}=3$; $\left.\chi^{2}=8.48 ; p=0.04\right)$.

\section{Monthly dynamics of $\mathrm{C}$ and $\mathrm{N}$} concentrations

At the beginning of the study period, we detected a brief drop in the miscellaneous $C$ concentration (Fig. 1). However, after reaching values of around $46.5 \%$, its dynamic remained almost constant from February 2011 for all the thinning treatments. Especially from that time forward, the $\mathrm{N}$ concentration showed similar trends among thinning treatments, with lower values from the last months of winter to early summer and maximums in autumn. An exception was found during the first months, when the T75 treatment showed higher $\mathrm{N}$ concentrations than the other intensities.

Differences were found between intermediate thinning intensities, T60 and T48, and T75 for $\mathrm{N}$ concentration over time by RM-ANOVA analyses $(\mathrm{df}=3, \mathrm{~F}=3.94, \mathrm{p}<$ $0.05)$. Contrarily, the To treatment registered no difference with respect to the thinned plots. Significant monthly differences were found for the concentrations in both miscellaneous $\mathrm{C}$ and $\mathrm{N}$ ( $\mathrm{df}=31, \mathrm{~F}=$ 26.80, $\mathrm{p}<0.001$; and $\mathrm{df}=31, \mathrm{~F}=14.92, \mathrm{p}<$ 0.001 , respectively) while significant interaction between sampling periods and thinning treatments was observed only for $C$ concentrations $(d f=93, F=1.71, p<0.01)$.

\section{Monthly dynamics of $C$ and $N$ pools}

Clear dynamics and similar trends appeared for each thinning treatment in $C$ and $\mathrm{N}$ pools in miscellaneous fraction (Fig.
2). In general, these pools were found during the spring and summer. In particular, the maximum peaks were found during the spring of 2011, and especially of 2013 in To.

The results of the RM-ANOVA revealed no differences between thinning treatments, either in $\mathrm{C}$ or in $\mathrm{N}$ pools over time. Significant monthly differences were found for both pools of $\mathrm{C}$ and $\mathrm{N}$ in the miscellaneous fraction $(\mathrm{df}=31, \mathrm{~F}=10.52, \mathrm{p}<0.001$; and $\mathrm{df}$ $=31, F=10.35, p<0.001$, respectively), while significant interactions between sampling periods and thinning treatments were observed only for $C(d f=93, F=1.30, p<0.05)$.

Annual amounts of $C$ and nutrient pools ANOVA results did not show differences among the thinning treatments in the first year and in the third year of the study for $C$ and $\mathrm{N}$ pools (Tab. 3 ).

In the second year of the study, signifi-

Tab. 3 - Results of one-way ANOVA and Kruskal-Wallis tests for total mean carbon and nutrients $\left(\mathrm{kg} \mathrm{ha}^{-1} \mathrm{yr}^{-1}\right)$ in the miscellaneous Pinus halepensis litterfall fraction under the four thinning intensities $(\mathrm{N}=4)$ after 3 years for $\mathrm{C}$ and $\mathrm{N}$, and after 2 years for the rest of macro- and micronutrients. $\mathrm{C}$ and $\mathrm{N}$ were measured over 36 months (from June 2010 to May 2013). P, K, Ca, Mg, Na, Mn, Fe, and Zn were measured over 24 months (from June 2011 to May 2013). (df): degrees of freedom.

\begin{tabular}{|c|c|c|c|c|c|c|c|c|c|c|c|c|}
\hline Period & Stats [df] & C & $\mathrm{N}$ & Stats [df] & $\mathbf{P}$ & K & $\mathrm{Ca}$ & $\mathrm{Mg}$ & $\mathrm{Na}$ & $M n$ & $\mathrm{Fe}$ & $\mathrm{Zn}$ \\
\hline \multirow[t]{2}{*}{ June 2010-May 2011} & $\mathrm{~F}_{[3]}$ & 2.60 & 1.93 & . & - & - & - & - & - & - & - & - \\
\hline & p-value & 0.0537 & 0.1260 & - & - & - & - & - & - & - & - & - \\
\hline \multirow[t]{2}{*}{ June 2011-May 2012} & $\mathrm{~F}_{[3]}$ & 22.00 & 20.28 & $\chi_{[3]}^{2}$ & 4.76 & 6.20 & 5.77 & 4.36 & 2.26 & 14.09 & 7.71 & 7.09 \\
\hline & $\mathrm{p}$-value & 0.0001 & 0.0001 & $\mathrm{p}$-value & 0.1900 & 0.1021 & 0.1234 & 0.2250 & 0.5204 & 0.0028 & 0.0524 & 0.0691 \\
\hline \multirow[t]{2}{*}{ June 2012-May 2013} & $\mathrm{~F}_{[3]}$ & 1.45 & 2.11 & $\chi_{[3]}^{2}$ & 14.90 & 10.95 & 11.47 & 14.55 & 3.78 & 15.53 & 21.14 & 15.94 \\
\hline & $\mathrm{p}$-value & 0.2305 & 0.1003 & $\mathrm{p}$-value & 0.0019 & 0.0120 & 0.0078 & 0.0022 & 0.2864 & 0.0014 & 0.0001 & 0.0012 \\
\hline \multirow[t]{2}{*}{ June 2010-May 2013} & $\chi_{[3]}^{2}$ & 2.31 & 2.71 & $\mathrm{~F}_{[3]}$ & 1.04 & 0.85 & 1.08 & 0.96 & 0.43 & 0.66 & 0.56 & 0.99 \\
\hline & $\mathrm{p}$-value & 0.5094 & 0.4380 & $\mathrm{p}$-value & 0.4141 & 0.4969 & 0.3988 & 0.4460 & 0.7324 & 0.5924 & 0.6543 & 0.4340 \\
\hline
\end{tabular}


Tab. 4 - Annual amounts ( \pm standard deviation) of C, macronutrients (N, P, K, Ca, Mg, and Na), and micronutrients ( Mn, Fe, and Zn) in the miscellaneous fraction of Pinus halepensis litterfall under different thinning intensities $(\mathrm{N}=4)$. $\mathrm{C}$ and $\mathrm{N}$ were analysed for 36 months (June 2010-May 2013), and P, K, Na, Ca, Mg, Mn, Fe, and Zn were analysed for 24 months (June 2011-May 2013). Thinning treatments: (T75): $75 \%$ of basal area removed; (T60): 60\%; (T48): 48\%, (To): no thinning. Different letters indicate statistical differences among treatments $(\mathrm{p}<0.05)$ after one-way ANOVA or Kruskal-Wallis tests.

\begin{tabular}{|c|c|c|c|c|c|c|c|c|c|c|c|}
\hline \multirow{2}{*}{$\begin{array}{l}\frac{0}{0} \\
\frac{0}{0} \\
0\end{array}$} & \multirow{2}{*}{ 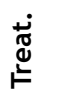 } & \multirow{2}{*}{$\begin{array}{l}\mathrm{C} \\
\left(\mathrm{kg} \mathrm{ha}^{-1}\right)\end{array}$} & \multicolumn{6}{|c|}{ Macronutrients (kg ha-1) } & \multicolumn{3}{|c|}{ Micronutrients $\left(\mathrm{g} \mathrm{ha}^{-1}\right)$} \\
\hline & & & $\mathrm{N}$ & $\mathbf{P}$ & K & $\mathrm{Ca}$ & $\mathrm{Mg}$ & $\mathrm{Na}$ & $\mathrm{Mn}$ & $\mathrm{Fe}$ & $\mathrm{Zn}$ \\
\hline \multirow{4}{*}{ 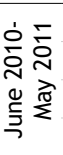 } & T75 & $26.17 \pm 56.15^{a}$ & $0.45 \pm 0.77^{\mathrm{a}}$ & - & - & - & - & 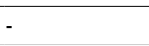 & - & - & - \\
\hline & T60 & $37.79 \pm 66.19^{\mathrm{a}}$ & $0.55 \pm 0.83^{a}$ & - & - & - & - & - & - & - & - \\
\hline & $\mathrm{T} 48$ & $41.66 \pm 76.99^{\mathrm{a}}$ & $0.70 \pm 1.06^{\mathrm{a}}$ & - & - & - & - & - & - & - & - \\
\hline & T0 & $50.78 \pm 111.48^{a}$ & $0.85 \pm 1.53^{a}$ & - & - & - & - & - & - & - & - \\
\hline \multirow{4}{*}{ 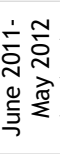 } & $\mathrm{T} 75$ & $6.19 \pm 8.08^{a}$ & $0.14 \pm 0.16^{a}$ & $0.03 \pm 0.02^{a}$ & $0.03 \pm 0.02^{a}$ & $0.99 \pm 0.46^{a}$ & $0.09 \pm 0.06^{a}$ & $0.01 \pm 0.01^{\text {a }}$ & $1.23 \pm 0.48^{a}$ & $26.01 \pm 15.83^{\text {a }}$ & $0.66 \pm 0.43^{a}$ \\
\hline & T60 & $9.83 \pm 9.65^{b}$ & $0.21 \pm 0.22^{\mathrm{ab}}$ & $0.05 \pm 0.03^{a}$ & $0.05 \pm 0.03^{a}$ & $1.27 \pm 0.47^{\mathrm{a}}$ & $0.13 \pm 0.06^{a}$ & $0.01 \pm 0.01^{\mathrm{a}}$ & $1.87 \pm 0.72 \mathrm{ab}$ & $38.22 \pm 22.89^{\mathrm{ab}}$ & $0.86 \pm 0.43^{a}$ \\
\hline & T48 & $16.35 \pm 28.04^{b}$ & $0.31 \pm 0.35^{b}$ & $0.09 \pm 0.09^{a}$ & $0.11 \pm 0.12^{a}$ & $2.74 \pm 2.51^{a}$ & $0.29 \pm 0.30^{\mathrm{a}}$ & $0.04 \pm 0.05^{a}$ & $7.10 \pm 6.69^{b}$ & $79.99 \pm 65.90^{\mathrm{b}}$ & $1.71 \pm 1.38^{a}$ \\
\hline & T0 & $13.92 \pm 14.57^{b}$ & $0.31 \pm 0.28^{b}$ & $0.05 \pm 0.02^{\text {a }}$ & $0.06 \pm 0.03^{a}$ & $1.73 \pm 0.65^{\mathrm{a}}$ & $0.14 \pm 0.06^{a}$ & $0.01 \pm 0.01^{\text {a }}$ & $3.07 \pm 1.04$ ab & $59.18 \pm 43.38$ ab & $1.14 \pm 0.38^{a}$ \\
\hline \multirow{4}{*}{ 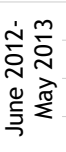 } & $\mathrm{T} 75$ & $38.57 \pm 67.22^{\mathrm{a}}$ & $0.47 \pm 0.73^{a}$ & $0.09 \pm 0.11^{a}$ & $0.09 \pm 0.10^{a}$ & $2.70 \pm 3.76^{\mathrm{a}}$ & $0.29 \pm 0.38^{a}$ & $0.12 \pm 0.21^{\mathrm{a}}$ & $8.30 \pm 14.72^{a}$ & $59.98 \pm 64.26^{\mathrm{a}}$ & $1.83 \pm 2.04^{\mathrm{a}}$ \\
\hline & $\mathrm{T} 60$ & $59.86 \pm 104.06^{a}$ & $0.68 \pm 1.05^{a}$ & $0.15 \pm 0.18^{a}$ & $0.14 \pm 0.18^{\mathrm{ab}}$ & $4.21 \pm 5.11^{\mathrm{ab}}$ & $0.43 \pm 0.57^{\mathrm{a}}$ & $0.13 \pm 0.21^{\mathrm{a}}$ & $9.11 \pm 11.34$ ab & $113.76 \pm 136.83^{a b}$ & $2.69 \pm 2.78^{a}$ \\
\hline & $\mathrm{T} 48$ & $66.94 \pm 123.34^{\mathrm{a}}$ & $0.79 \pm 1.19^{a}$ & $0.17 \pm 0.22^{\mathrm{ab}}$ & $0.19 \pm 0.33^{a b}$ & $4.54 \pm 6.94^{\mathrm{ab}}$ & $0.46 \pm 0.63^{a b}$ & $0.07 \pm 0.08^{a}$ & $23.99 \pm 50.35^{\mathrm{ab}}$ & $137.84 \pm 162.63^{b}$ & $3.01 \pm 2.98 \mathrm{ab}$ \\
\hline & T0 & $131.42 \pm 327.40^{\mathrm{a}}$ & $1.60 \pm 3.47^{\mathrm{a}}$ & $0.44 \pm 0.64^{b}$ & $0.47 \pm 0.85^{b}$ & $14.20 \pm 23.47^{\mathrm{b}}$ & $1.43 \pm 2.33^{b}$ & $0.45 \pm 0.84^{\mathrm{a}}$ & $36.28 \pm 57.06^{b}$ & $235.27 \pm 240.76^{b}$ & $9.51 \pm 14.04^{b}$ \\
\hline
\end{tabular}

cant differences in $\mathrm{C}$ pools were registered differed from $\mathrm{T} 48$.

between $\mathrm{T} 75$ and the other treatments (Tab. 4). $\mathrm{N}$ pools were significantly higher in T48 and To than in T75 but none differed from T60. Significant differences were also detected among the thinning treatments for $\mathrm{Mn}$ and $\mathrm{Fe}$.

In the third year of the study, we found significant differences between T75 and To for $\mathrm{P}, \mathrm{K}, \mathrm{Ca}, \mathrm{Mg}, \mathrm{Mn}, \mathrm{Fe}$, and $\mathrm{Zn}$ pools (Tab. 4). $P, M g$, and $Z n$ pools were also significantly higher in To than in T60. ANOVA results did not show significant differences among T75, T60, and T48 for P, K, Ca, Mg, $\mathrm{Mn}$, and $\mathrm{Zn}$. For Fe pools, T75 significantly

\section{Total $\mathrm{C}$ and nutrients pools}

No statistical differences among thinning intensities were found for total mean $\mathrm{C}$ and $\mathrm{N}$ in the miscellaneous fraction after 36 months (Tab. 3). Similarly, no statistical differences among thinning intensities were found for total mean P, K, Ca, Mg, Na, Mn, $\mathrm{Fe}$, and $\mathrm{Zn}$ in the miscellaneous fraction after 24 months.

\section{Comparison between miscellanea and} needlefall

No significant differences between both litterfall fractions were found for $\mathrm{C}, \mathrm{N}, \mathrm{Na}$, and Fe pools (Fig. 3). Significant higher pools in needlefall were found for some nutrients and treatments. $\mathrm{Ca}, \mathrm{Mg}$, and $\mathrm{Mn}$ pools in needlefall were significantly higher than in miscellanea for T60 and T48. P and Zn pools in needlefall were higher in $\mathrm{T} 48$, and higher needlefall pools of $K$ were found in T75 and T48. Miscellaneous fraction showed significant lower $\mathrm{C} / \mathrm{N}$ ratios than needlefall for the four thinning treatments (Fig. 3).

The percentage of annual mean pools in the miscellanea $\left(\mathrm{kg} \mathrm{ha}^{-1} \mathrm{yr}^{-1}\right)$ regarding the total litterfall (needlefall and miscellaneous
Fig. 3 - Total mean pools of $\mathrm{C}$ and $\mathrm{N}\left(\mathrm{kg} \mathrm{ha}^{-1}\right)$ after 3 years (2010-2013) in needlefall and in miscellaneous fraction in Pinus halepensis afforestation for each thinning treatment (mean \pm standard deviation). Total mean of $\mathrm{P}, \mathrm{K}, \mathrm{Ca}, \mathrm{Mg}, \mathrm{Na}$, $\mathrm{Mn}, \mathrm{Fe}$, and $\mathrm{Zn}$ pools ( $\mathrm{kg}$ $\mathrm{ha}^{-1}$ ) after 2 years (20112013) in needlefall and miscellaneous fraction in Pinus halepensis afforestation for each thinning treatment (mean \pm standard deviation). (T75): $75 \%$ of basal area removed; (T60): 60\% of basal area removed; (T48): $48 \%$ of basal area removed; (To): no thinning. Asterisks indicate a significant difference in the paired t-test.
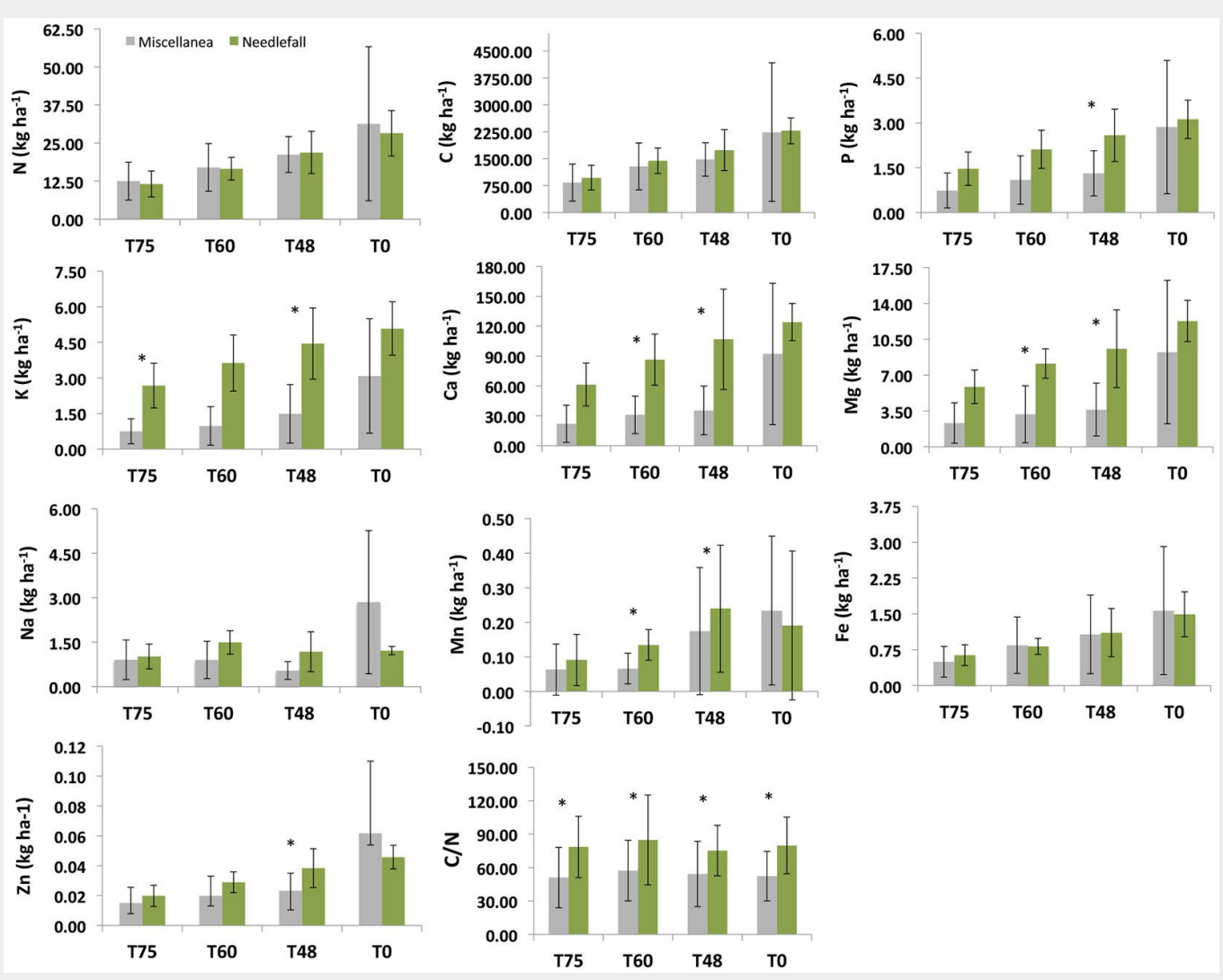
fraction together) varied from $45.9 \%$ to $49.5 \%$ for C, from $49.2 \%$ to $52.6 \%$ for N, from $43.0 \%$ to $57.9 \%$ for $P$, from $26.5 \%$ to $43.3 \%$ for $\mathrm{K}$, from $32.8 \%$ to $51.9 \%$ for $\mathrm{Ca}$, and from $34.9 \%$ to $51.0 \%$ for Mg (see Fig. S1 in Supplementary Material). Annual mean pools of micronutrients in the miscellaneous fraction represented between $33.3 \%$ and $63.2 \%$ of the annual mean nutrient pools.

\section{Discussion}

\section{Carbon and nutrient concentrations}

Mean $\mathrm{C}$ and $\mathrm{N}$ concentrations recorded in the present study were similar to values found by several authors for the miscellaneous fraction in pine species, or another equivalent fraction (Blanco et al. 2008, Díaz-Pinés et al. 2011, Lado-Monserrat et al. 2016). By contrast, higher variability was found for $\mathrm{P}, \mathrm{K}, \mathrm{Ca}$, and $\mathrm{Mg}$ concentrations in comparison with the Pinus sylvestris $\mathrm{L}$. no-needlefall fraction, and lower $\mathrm{Mn}$ and Zn concentrations, mainly because miscellanea materials differed depending on the authors consulted (Finér 1996, Blanco et al. 2008). In general, the varied classification of litterfall fractions was the main issue in order to compare our results with literature (see Tab. S1 in Supplementary Material). Moreover, due to the fact that this material classified as no-needle, called "miscellaneous", "other litter", etc., is usually considered highly variable and/or minority fraction, it is often not analysed (Gosz et al. 1972, Roig et al. 2005, Berg \& McClaugherty 2008, Zhou et al. 2014).

Similarly, few studies have reported the effects of thinning on nutrient concentrations from other litter fractions different from needlefall, and no reference has been found for Aleppo pine afforestation in semiarid regions. According to our results, thinning did not affect mean nutrient concentrations in the miscellaneous fraction, with the exception of $\mathrm{N}$, in which the effect was highly variable. The nearest reference to compare our results has been the study of the effects of thinning on miscellaneous fraction from a natural $P$. halepensis forest (Lado-Monserrat et al. 2016), where differences were detected only for $\mathrm{K}$ and $\mathrm{Mg}$ concentrations between the most thinned plots and the unthinned ones. For P. sylvestris, Blanco et al. (2008) found no difference among thinning treatments in nutrient concentrations from "other pine material" (branches, cones, bark, and reproductive organs), and "miscellaneous" (materials other than pine) fractions. In our case, differences between thinning intensities were also found in $\mathrm{N}$-concentration dynamics over time, which trends may indicate some points in the life cycle of the pine processionary (Thaumetopoea pityocampa). Indeed, nest and frass from insects contained less $\mathrm{N}$ than did the green needles on which they feed, according to the foliar nutrient concentrations reported by Jiménez \& Navarro (2015). During spring, the $\mathrm{N}$ concentration could be diluted due to other fallen materials poor in N. In addition, dynamics in $\mathrm{N}$ and $\mathrm{C}$ concentration in the miscellany could also reflect remains falling from another pest and pine organs (buds, seeds, flowers, pollen, etc.) during the study period. This material heterogeneity could explain the lack of clear trends, mainly in $C$ concentration.

\section{Pools of $C$ and nutrients}

On the whole, the effects of thinning on the amount of miscellaneous $C$ and nutrient pools varied depending on the period studied, this being erratic in many cases. Due to the monitoring litterfall started 5 years after the treatments, possible effects just after thinning could not have been detected and they could have dissipated over time. Also, we suspect that significant differences among thinning intensities could have been found with more intensive spatial and/or temporal monitoring.

On the one hand, thinning did not affect $\mathrm{C}$ and $\mathrm{N}$ pool dynamics over time but the sampling period determined the changes in $\mathrm{C}$ and $\mathrm{N}$ pools. In fact, both periodic climatic events (storm, heavy rain, and wind) and insect pest have been associated with monthly peaks in miscellanea for several pine species and climates (Gosz et al. 1972, Finér 1996, Kim et al. 1996, Li et al. 2005, Zhou et al. 2014). Jiménez \& Navarro (2016) remarked on the miscellaneous fraction seasonality, with the maximum amounts recorded in April and May. Therefore, peaks in $\mathrm{N}$ and $\mathrm{C}$ pools recorded in spring of 2011 and 2013, especially in April (Fig. 2), are consistent with the fall of the caterpillar nest and frass after pest attack registered by the Integrated Fighting Plan for the processionary moth of the Andalusian Government (data no published). Accordingly, the degree of the pest attack was the lowest during 2012 (level 1 from 4) whereas more pest caterpillars were found during spring 2013 (level 3) and, to a lesser extent, 2011 (level 2). However, the peak of miscellanea found in July 2010 could be explained by the wind registered by the sensors installed in the weather station from Cortijo del Conejo. During the first week in July 2010, wind speed varied from 15.12 to 22.32 $\mathrm{km} \mathrm{h}^{-1}$, while the mean recorded for the summer was $4.10 \pm 3.9 \mathrm{~km} \mathrm{~h}^{-1}$. Sporadic peaks outside summer in $P$. halepensis litterfall caused by unusually strong winds have been reported by several authors, such as García-Plé et al. (1995), who also recorded maximums in bud-scale and inflorescence fall at the end of winter and the beginning of spring. It could be that a minor amount of these components also fall before the remains of the pine processionary, but their influence was not significant.

On the other hand, we observed high heterogeneity in the annual amounts of miscellaneous pools, as well as different thinning effects (Tab. 4). Although we are conscious that more years would be needed to reinforce our results, the treatment intensity reduced the pools of $\mathrm{C}$, macro- and $\mathrm{mi}$ - cronutrients in the first and the third year of the study (2010-2011 and 2012-2013). Despite that thinning differences in annual amount of miscellany were not found by Jiménez \& Navarro (2016), in some cases and mostly in the third year, significant thinning effects between the unthinned and T75 treatment could indicate an influence of the nutrient concentrations on the pools (i.e., no dilution effects). Two consequences of miscellaneous amounts reported by these authors arise in our 20112012 nutrient pools results. Firstly, the $C$ and nutrient pools for that year were lower. Secondly, the pools registered were higher in T48 treatments, although with no significant differences among thinning intensities for most of the nutrients.

Despite the fact that $P$. sylvestris is one of the most widely studied pine species, the studies incorporating thinning effects on litterfall are also scarce (Del Río et al. 2017). For example, Blanco et al. (2008) reported $\mathrm{N}, \mathrm{P}, \mathrm{K}, \mathrm{Ca}$, and $\mathrm{Mg}$ nutrient return to the soil through litterfall fractions (needlefall, other pine material, and miscellaneous) but found no differences among thinning treatments for other litterfall fractions than needlefall. Bearing in mind the differences in litter fraction composition, mainly for the higher pine densities (To and T48), we calculated similar mean annual pools of $\mathrm{N}$ and $\mathrm{P}$ in miscellany to their inputs through "other pine material" and "miscellaneous" fractions in the Mediterranean site studied by these authors. However, the total mean annual $\mathrm{N}$ was higher than our values because of the $\mathrm{N}$ inputs from needlefall. Only the annual values reported for K in "miscellaneous" were comparable to our findings in the unthinned stands, because, in general, they registered higher mean pools of K. Similarly, in 50-year-old reforested $P$. sylvestris stands, Santa Regina \& Tarazona (2001) reported higher annual $\mathrm{N}$ inputs to the soil via flowers and other plant material than our findings, mainly because of greater DBH and annual litterfall production. However, in their case, the annual amount of $P$ found was notably lower. Also, Finér (1996) reported annual production via "other litter" from Scots pine similar to the values for miscellany in our T75 stands, as well as slightly less N, P, K, Mn, Fe, and Zn. However, Ca and $\mathrm{Mg}$ deposition was at least 10-fold higher in our case, presumably due to the composition of the material, consisting of branches, cones, flowers, bark, and fine litter.

\section{C and nutrient pools in litterfall:} miscellaneous fraction vs. needlefall

For Aleppo pine, relatively few references have been found about mean pools of $C$, micro, and macronutrients in the litterfall. For example, Michopoulos et al. (2007) showed one-year results similar to our mean pools in needlefall plus the miscellany of $\mathrm{N}, \mathrm{P}, \mathrm{Ca}, \mathrm{Mg}, \mathrm{Mn}$, and $\mathrm{Fe}\left(\mathrm{kg} \mathrm{ha}^{-1}\right)$, but higher $\mathrm{K}$ and $\mathrm{Zn}$ pools. Moreover, we 
found similar annual mean pools of $\mathrm{C}, \mathrm{N}$, and $\mathrm{K}$ in the litterfall to Lado-Monserrat et al. (2016), which added up all litterfall components. However, our $\mathrm{P}, \mathrm{Ca}$, and $\mathrm{Mg}$ pools were higher than the values provided by these authors.

In this sense, annual $C$ pool in litterfall (needlefall and miscellany) seems to be in the lower range limit found for pine species in Mediterranean areas pointed out by Díaz-Pinés et al. (2011), i.e., 1.5-2 Mg C ha $\mathrm{yr}^{-1}$. In an 80-year-old Scots pine stand, these authors reported a slightly higher $\mathrm{C}$ input of total litterfall (1.8-2.4 Mg C ha-1 $\left.\mathrm{yr}^{-1}\right)$ than our findings, which varied between $0.6 \mathrm{Mg} \mathrm{C} \mathrm{ha}^{-1} \mathrm{yr}^{-1}$ and $1.5 \mathrm{MgC} \mathrm{ha}^{-1} \mathrm{yr}^{-1}$, depending on the thinning intensities.

In our study, approximately half the amount of the main nutrient pools in litterfall was provided by the miscellaneous fraction. Marked variability could be found regarding the biomass production from each litterfall fraction among forests depending on factors such as climate, species, forest management, stand characteristics, and pests (Santa Regina \& Tarazona 2001, Blanco et al. 2008, Díaz-Pinés et al. 2011, Jiménez \& Navarro 2016). For instance, Gosz et al. (1972) reported annual inputs from overstory litterfall via miscellaneous fraction in an undisturbed mature forest, consisting of fragments of unidentified species of leaf tissue, buds, and frass, which together could be similar to our miscellanea category, in the range of our results for N, P, K, Mn, and Zn. However, these authors found a lower annual amount of $\mathrm{Ca}, \mathrm{Mg}, \mathrm{Na}$, and Fe returning to the soil.

In view of our results and according to several authors, fractions other than needlefall could also have key importance on nutrient pools and, related to it, nutrients return to the soil (Santa Regina \& Tarazona 2001, Blanco et al. 2008). Indeed, no remarkable differences between needlefall and miscellaneous pools were found in three years for $\mathrm{C}$ and $\mathrm{N}$, and in two years for the rest of the nutrients studied, except sporadic significant differences found in some thinning treatments. However, a higher $\mathrm{C} / \mathrm{N}$ ratio in needlefall indicated lower quality of this litterfall fraction regarding miscellanea. This result could suggest a slower $\mathrm{N}$ return to the soil via needlefall than via miscellanea (Gelfand et al. 2012).

These results could be useful for the scientific community, land managers, and policy makers in order to make decisions relative to carbon sequestration alternatives and adaptation strategies in the present climate-change context (Paul et al. 2018). Although thinning may temporarily reduce the $C$ and nutrient content in litterfall at least at mid-term, this forest management is highly recommended to improve the pine afforestation resilience and to prevent future pest attacks or wildfires, which are expected to increase in frequency and intensity as a consequence of climate change in Mediterranean areas (Hódar et al. 2012, Segura et al. 2017, Jiménez et al. 2019).

\section{Conclusion}

We provide evidence that $C$ and nutrients pools in the miscellaneous fraction of litterfall in a semi-arid Aleppo pine afforestation are the same or greater than in needlefall. This fraction peaks coincided mainly with the fall of the nest and frass from the pine processionary. Therefore, the insect-pest life cycling could play a major role in the seasonality of the $\mathrm{C}$ and nutrient inputs to the soil. Also, strong climatic episodes, such as windstorms, could have important effects. In our case, we found a high degree of seasonality in the $C$ and nutrient pools, with two main peaks in the recycling patterns: during spring for miscellaneous fraction, and during summer for needlefall. Moreover, forest-management practices such as thinning seem a priori not to affect these patterns and the pools in the miscellaneous fraction, although we need to take into account that the data were recorded 5 years after treatments application, and the erratic and more variable miscellanea fraction could have required more intensive spatial and temporal monitoring. In this sense, further studies analysing the important role of the miscellanea fraction of litterfall in forest ecosystems should be conducted, especially in Mediterranean environments.

\section{Acknowledgements}

The authors wish to thank E. Gallego, L. Terrón, and A. Sánchez-Miranda for their invaluable help in the field work. Thanks go to D. Nesbitt for his English review.

This study was funded by Egmasa (Government of Andalucía, Spain) through the project "Grazed fuelbreaks as a fire-preventive silvicultural tool in Mediterranean forestlands". We also thank the INIA and FEDER for financial support provided by project SUM2008-00003-C03.

\section{References}

Andivia E, Bou J, Fernández M, Caritat A, Alejano R, Vilar L, Vázquez-Piqué J (2018). Assessing the relative role of climate on litterfall in Mediterranean cork oak forests. iForest 11: 786-793. doi: 10.3832/ifor2825-011

Berg B, McClaugherty C (2008). Plant litter. Decomposition, humus formation, carbon sequestration ( $2^{\text {nd }}$ edn). Springer-Verlag, Berlin, Germany, pp. 286.

Berg B, Meentemeyer V (2001). Litter fall in some European coniferous forests as dependent on climate: a synthesis. Canadian Journal of Forest Research 31: 292-301. - doi: 10.1139/ xo0-172

Bernier P, Hanson PJ, Curtis PS (2008). Measuring litterfall and branchfall. In: "Field Measurements for Forest Carbon Monitoring" (Hoover CM ed). Springer, Dordrecht, Netherlands,, pp. 91-101. - doi: 10.1007/978-1-4020-8506-2_7 Blanco JA, Imbert JB, Castillo FJ (2006). Influence of site characteristics and thinning intensity on litterfall production in two Pinus sylv- estris L. forests in the western Pyrenees. Forest Ecology and Management 237: 342-352. - doi: 10.1016/j.foreco.2006.09.057

Blanco JA, Imbert JB, Castillo FJ (2008). Nutrient return via litterfall in two contrasting Pinus sylvestris forests in the Pyrenees under different thinning intensities. Forest Ecology and Management 256: 1840-1852. - doi: 10.1016/j.for eco.2008.07.011

Del Río M, Bravo-Oviedo A, Pretzsch H, Löf $M$, Ruiz-Peinado $R$ (2017). A review of thinning effects on Scots pine stands: from growth and yield to new challenges under global change. Forest Systems. 26: eR03S. - doi: 10.5424/fs/20 17262-11325

Díaz-Pinés E, Rubio A, Montes F (2011). Aboveground soil $C$ inputs in the ecotone between Scots pine and Pyrenean oak in Sierra de Guadarrama. Forest Systems 20: 485-495. - doi: 10.5424/fs/20112003-11083

Espinosa J, Madrigal J, De La Cruz AC, Guijarro M, Jimenez E, Hernando C (2018). Short-term effects of prescribed burning on litterfall biomass in mixed stands of Pinus nigra and Pinus pinaster and pure stands of Pinus nigra in the Cuenca Mountains (Central-Eastern Spain). Science of Total Environment 618: 941-951. - doi: 10.1016/j.scitotenv.2017.08.291

FAO/ISRIC (1998). World reference base for soil resources. Food and Agriculture Organization for the United Nations, Rome, Italy, pp. 84.

Finér L (1996). Variation in the amount and quality of litterfall in a Pinus sylvestris L. stand growing on a bog. Forest Ecology and Management 80: 1-11. - doi: 10.1016/0378-1127(95)03652-0

García-Plé C, Vanrell P, Morey M (1995). Litter fall and decomposition in a Pinus halepensis forest on Mallorca. Journal of Vegetation Science 6: 17-22. - doi: 10.2307/3236251

Gelfand I, Grünzweig JM, Yakir D (2012). Slowing of nitrogen cycling and increasing nitrogen use efficiency following afforestation of semi-arid shrubland. Oecologia 168: 563-575. - doi: 10.100 7/s00442-011-2111-0

Gosz JR, Likens GE, Bormann FH (1972). Nutrient content of litter fall on the Hubbard Brook experimental forest, New Hampshire. Ecology 53 (5): 769-784. - doi: 10.2307/1934293

Hódar JA, Zamora R, Cayuela L (2012). Climate change and the incidence of a forest pest in Mediterranean ecosystems: can the North Atlantic Oscillation be used as a predictor? Climatic Change 113: 699-711. - doi: 10.1007/s10584011-0371-7

Jiménez MN, Navarro FB (2015). Monthly foliarnutrient pattern in a semiarid Aleppo pine plantation five years after thinning. Forest Ecology and Management 343: 63-72. - doi: 10.1016/j.for eco.2015.01.032

Jiménez MN, Navarro FB (2016). Thinning effects on litterfall remaining after 8 years and improved stand resilience in Aleppo pine afforestation (SE Spain). Journal of Environmental Management 169: 174-183. - doi: 10.1016/j.jenv man.2015.12.028

Jiménez MN, Navarro FB, Sánchez-Miranda A, Ripoll MA (2019). Using stem diameter variations to detect and quantify growth and relationships with climatic variables on a gradient of thinned Aleppo pines. Forest Ecology and Management 442: 53-62. - doi: 10.1016/j.foreco. 
2019.03.061

Johnson C, Chhin S, Zhang J (2017). Effects of climate on competitive dynamics in mixed conifer forests of the Sierra Nevada. Forest Ecology and Management 394: 1-12. - doi: 10.1016/j.for eco.2017.03.017

Kim C, Sharik TL, Jurgensen MF, Kim C, Sharik TL, Jurgensen MF (1996). Litterfall, nitrogen and phosphorus inputs at various levels of canopy removal in oak and pine stands in Northern Lower Michigan. The American Midland Naturalist 135: 195-204. - doi: 10.2307/2426702

Lado-Monserrat L, Lidón A, Bautista I (2016). Litterfall, litter decomposition and associated nutrient fluxes in Pinus halepensis: influence of tree removal intensity in a Mediterranean forest. European Journal of Forest Research 135: 203-214. - doi: 10.1007/s10342-015-0893-z

Li ZA, Zou B, Xia HP, Ren H, Mo JM, Weng $H$ (2005). Litterfall dynamics of an evergreen broadleaf forest and a pine forest in the subtropical region of China. Forest Science 51: 608615. [online] URL: http://academic.oup.com/for estscience/article/51/6/608/4617625

Michopoulos P, Baloutsos G, Economou A, Samara C, Thomaidis NS, Grigoratos T (2007). Nutrient cycling and foliar status in an urban pine forest in Athens, Greece. Plant and Soil 294: 31-39. - doi: 10.1007/s11104-007-9224-6

Navarro FB, Romero-Freire A, Del Castillo T, Foronda A, Jiménez MN, Ripoll MA, SánchezMiranda A, Huntsinger L, Fernández-Ondoño E (2013). Effects of thinning on litterfall were found after years in a Pinus halepensis afforestation area at tree and stand levels. Forest Ecology and Management 289: 354-362. - doi: 10.1016/j.foreco.2012.09.026
Paul KI, England JR, Baker TG, Cunningham SC, Perring MP, Polglase PJ, Wilson B, Cavagnaro TR, Lewis T, Read Z, Madhavan DB, Herrmann T (2018). Using measured stocks of biomass and litter carbon to constrain modelled estimates of sequestration of soil organic carbon under contrasting mixed-species environmental plantings. Science of the Total Environment 615: 348359. - doi: 10.1016/j.scitotenv.2017.09.263

Portillo-Estrada $M$, Korhonen JFJ, Pihlatie $M$, Pumpanen J, Frumau AKF, Morillas L, Tosens T, Niinemets U (2013). Inter- and intra-annual variations in canopy fine litterfall and carbon and nitrogen inputs to the forest floor in two European coniferous forests. Annals of Forest Science 70: 367-379. - doi: 10.1007/s13595-013-02730

Roig S, Del Río M, Cañellas I, Montero G (2005). Litter fall in Mediterranean Pinus pinaster Ait. stands under different thinning regimes. Forest Ecology and Management 206: 179-190. - doi: 10.1016/j.foreco.2004.10.068

Ruiz-Peinado R, Bravo-Oviedo A, López-Senespleda E, Bravo F, Río M (2017). Forest management and carbon sequestration in the Mediterranean region - a review. Forest Systems 26: 125. - doi: 10.5424/fs/2017262-11205

Sánchez-Miranda A, Jiménez MN, Gálvez-Garrido CR, Navarro FB, Ripoll MA, Hevia A, SánchezSalguero R (2016). Thinning modulates climategrowth responses of Pinus halepensis Mill. under semiarid Mediterranean conditions. STR16/ 04 14: 111-119. - doi: 10.2312/GFZ.b103-16042 Santa Regina I, Tarazona T (2001). Nutrient pools to the soil through organic matter and throughfall under a Scots pine plantation in the Sierra de la Demanda, Spain. European Journal of Soil
Biology 37: 125-133. - doi: 10.1016/S1164-5563(01) 01072-X

Segura C, Fernández-Ondoño E, Jiménez MN, Navarro FB (2017). Thinning affects the needlefall nutrient return to soil in a semiarid Aleppo pine afforestation while the nutrient dynamics remain unchanged. Forest Ecology and Management 405: 257-270. - doi: 10.1016/j.foreco.20 17.09.049

Sohn JA, Saha S, Bauhus J (2016). Potential of forest thinning to mitigate drought stress: a meta-analysis. Forest Ecology and Management 380: 261-273. - doi: 10.1016/j.foreco.2016. 07.046

Ukonmaanaho L, Merilä P, Nöjd P, Nieminen TM (2008). Litterfall production and nutrient return to the forest floor in Scots pine and Norway spruce stands in Finland. Boreal Environmental Research 13: 67-91. [online] URL: http:// jukuri.luke.fi/handle/10024/514741

Zhou Y, Su J, Janssens IA, Zhou G, Xiao C (2014). Fine root and litterfall dynamics of three Korean pine (Pinus koraiensis) forests along an altitudinal gradient. Plant and Soil 374: 19-32. doi: 10.1007/s11104-013-1816-8

\section{Supplementary Material}

Tab. S1 - Litterfall fractions classification according to the authors consulted.

Fig. S1 - Total annual mean of carbon and nutrients ( $\mathrm{kg} \mathrm{ha} \mathrm{hr}^{-1}$ ) adding up inputs from needlefall and miscellaneous fraction.

Link: Segura_2907@supploo1.pdf 